УДК 574.5:561.26/.27(571.54)

\title{
О современном состоянии и многолетней динамике флоры и растительности озера Гусиное (Республика Бурятия)
}

\author{
Базарова Б. Б., Куклин А. П.
}

Институт природных ресурсов экологии и криологии Сибирского отделения РАН

Чита, Россия

balgit@mail.ru

В результате гидроботанических исследований, проведенных летом 2013-2014 годы на озере Гусиное (Республика Бурятия) было зарегистрировано 27 видов из 21 семейств. Установлено, что макрофиты произрастают до глубины 13,0 м. Показано, что современное состояние растительного покрова озера обусловлено комплексом факторов (строение литорали, динамика уровня воды, изменение температурного режима, состава вод и т. д.) как природного, так и антропогенного характера. В тоже время, в многолетнем аспекте, несмотря на значительную антропогенную нагрузку, доминантами растительности остаются Charophyta и Bryophyta. Появившийся в начале XX века чужеродный вид Elodea canadensis не оказывает явного влияния на аборигенные виды озера Гусиное.

Ключевые слова: водная растительность, экосистема озера, озеро Гусиное, харовые водоросли, мхи.

\section{ВВЕДЕНИЕ}

Озеро Гусиное - крупнейшее озеро на Байкальской природной территории после озера Байкал, интенсивно подвергающееся химическому и тепловому загрязнению. В озеро более 50 лет сбрасываются карьерные (шахтные) воды Хольбольджинского угольного разреза, возросло поступление недостаточно очищенных коммунально-бытовых вод из города Гусиноозерск. Озеро является водоёмом-охладителем Гусиноозерской тепловой электростанции, первый блок которой введен в строй в 1976 году, а шестой - в 1996 году. С 2014 года станция вышла на уровень мощности в 1100 МВт (Цыдыпов и др., 2017).

Озеро является ценным рыбохозяйственным водоемом, давно вызывает интерес краеведов, геологов и других исследователей (Кожов, 1950; Экология..., 1994; Гусиноозерская..., 2016). В начале XXI века внимание к озеру возросло в связи с ростом техногенной нагрузки и с появлением новой угрозы в виде биологических инвазий. Из компонентов экосистемы озера лучше всего изучены зоопланктон (Шевелева, 2015), зообентос (Семерной и др., 2014; Матафонов, Базова, 2018), популяции рыб (Бобков, Иметхенов 2011; Матвеев, 2017), паразитофауна рыб (Дугаров и др., 2017; Дугаров и др., 2018), а также бактериопланктон (Tsydenova et al., 2018). Практически неизученным оставался автотрофный блок. Информация о водных макрофитах имелась только по состоянию на 1927 (Гусиноозерская..., 2016), 1939 (Рыбопромысловая..., 1939) и 1947 годы (Кожов, 1950), причем, в этих работах были приведены данные лишь о массовых видах, создающих помехи рыбному промыслу. По состоянию на 1990-1991 годы имеются сведения о химическом составе Potamogeton praelongus Wulf (Экология..., 1994).

Цель данной работы - изучить современное состояние видового разнообразия и пространственной структуры водной и прибрежно-водной растительности озера Гусиное, а также проанализировать динамику растительности озера в многолетнем аспекте.

\section{МАТЕРИАЛЫ И МЕТОДЫ}

Озеро Гусиное имеет овальную форму, вытянутую с юго-запада на северо-восток (рис. 1). Площадь водосборного бассейна озера равна 924 км$^{2}$, площадь водного зеркала составляет 164 км$^{2}$, средний многолетний объем воды $-2,4$ км$^{3}$ при средней глубине 15 м. Длина - 


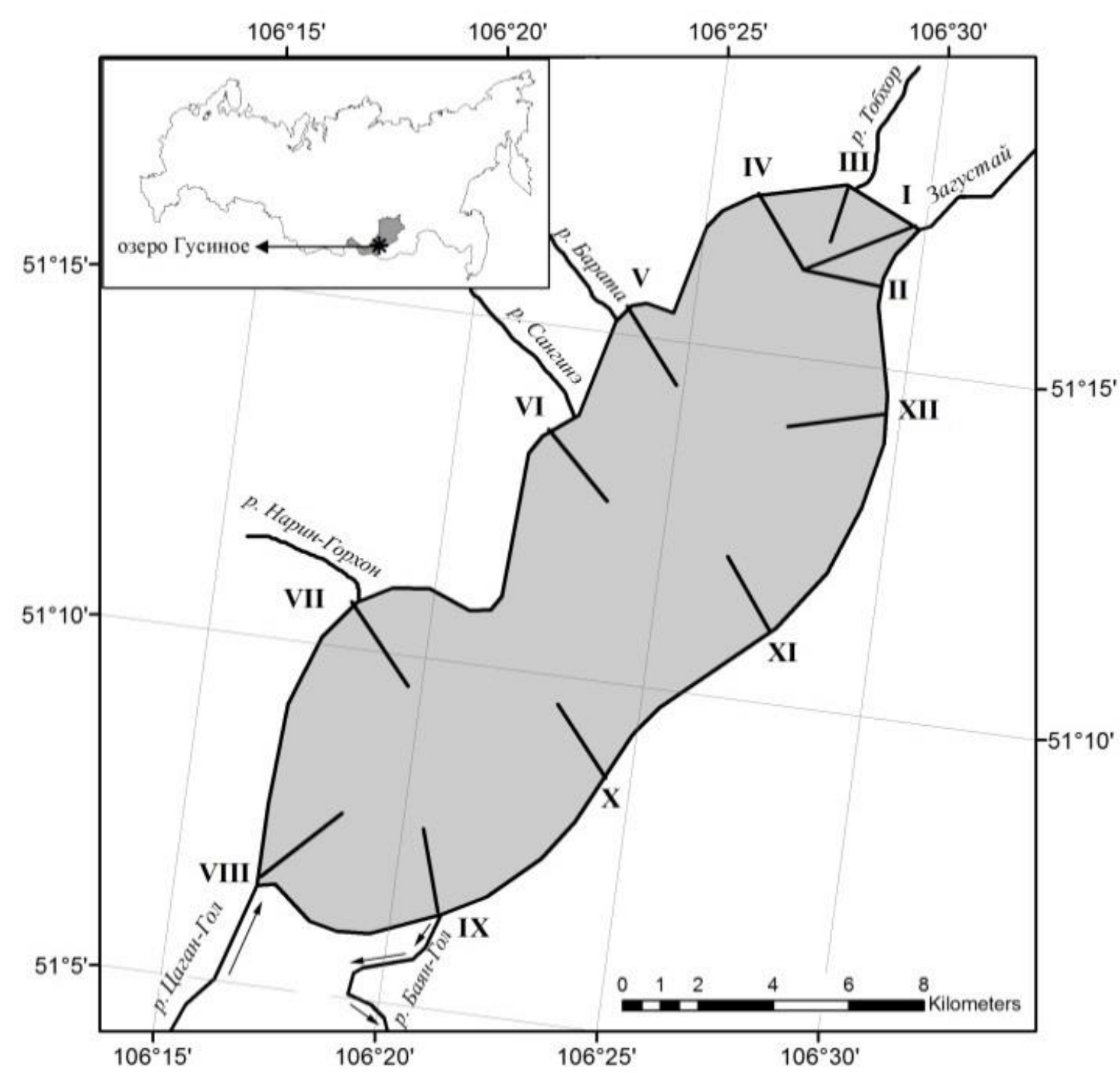

Рис. 1. Карта-схема озера Гусиное

Условные обозначения: I-XII - гидроботанические профили (пояснения в тексте).

24,8 км, средняя ширина - 8 км, наименьшая - 5,1 м, преобладающие глубины - 15-20 м, а наибольшая - 26 м. Чаша озера имеет корытообразную форму с двумя неравновеликими котловинами. Основные площади мелководий озера приурочены к северной и юго-западной прибрежным частям озера (Кожов, 1954; Богданов, 1977).

Озеро Гусиное относится к слабопроточным водоемам. Коэффициент условного водообмена равен 0,0125. В озеро впадает 9 рек, при высоком уровне воды вытекает река Баин-Гол в юго-восточной части озера. Береговая линия имеет плавные очертания, изредка усложняясь песчаными косами и конусами выноса устьев рек и несколькими неглубокими заливами в северо-восточной и юго-западной частях. С северо-запада в озеро вдается широкий мыс Чана, который сужает озеро и разделяет его на 2 котловины: южную (меньшую по площади, но более глубокую) и северную, занимающую основную часть озера (Экология..., 1994). Согласно В. Т. Богданову (1974) вскрытие озера ото льда происходило в мае, в июле - августе вода прогревалась до $15,0-21,5^{\circ} \mathrm{C}$. Увеличение объема теплых вод, сбрасываемых электростанцией непосредственно в озеро, привело к изменению его температурного режима. В настоящее время разрушение ледового покрова наблюдается в апреле - мае. Вследствие сброса подогретых вод в северной части водоема ледовый покров отсутствует весь зимний период. При этом площадь полыньи в течение зимы изменяется от 
0,336 до 1,76 км² (Чебунина и др., 2016). В зимнее время температуры воды в сбросном канале и акватории озера различаются на $14-16^{\circ} \mathrm{C}$, а в летнее - на $11-14^{\circ} \mathrm{C}$ (Цыдыпов и др., 2017). Распределение температур в толще воды озера достаточно равномерное: в зоне максимальных глубин различия между значениями поверхностного и придонного слоёв были в пределах 1,93,8 ${ }^{\circ} \mathrm{C}$. До строительства ГРЭС (1974 г.) озеро характеризовалось значительной прозрачностью воды (зимой - 15 м, летом - 11 м) (Богданов, 1974). В мае 2013 года прозрачность воды по диску Секки составила 7,5 м. Концентрации кислорода в воде (как в поверхностном, так и в придонном слоях) были высокими вплоть до полного насыщения (Матафонов, Базова, 2018).

Грунты в озере не отличаются большим разнообразием. Прибрежная часть до изобаты 6 м занята песчаными и песчано-галечными грунтами. Вся глубинная, а также прибрежная полоса вдоль западного берега покрыты вязкими илами черного, изредка серого цвета (Экология..., 1994; Матафонов, Базова, 2018).

За период с 1970 по 1987 год интенсивной эксплуатации озера в нем повысилась минерализация, сменился гидрохимический тип вод (табл. 1) Концентрация сульфатов увеличилась в 2 раза, а с 1950 по 1990 год - почти в 5 раз (Экология..., 1994).

Таблица 1

Динамика гидрохимического состава вод озера Гусиное

\begin{tabular}{|c|c|c|c|}
\hline \multirow{2}{*}{ Показатели } & \multicolumn{3}{|c|}{ Года } \\
\hline & $1974 *$ & $1990-1992 * *$ & $2016 * * *$ \\
\hline $\mathrm{HCO}_{3}^{-}$, мг/л & $114,1-183$ & $\begin{array}{c}\text { зима: 146-199, } \\
\text { лето: 115-165 }\end{array}$ & $198-214$ \\
\hline $\mathrm{SO}^{2-}{ }_{4}$ МГ/Л & $8,2-22,1$ & $35-67$ & $66-73$ \\
\hline $\mathrm{Ca}^{2}, \mathrm{мг/л}$ & $21,5-35,7$ & $24-32$ & $30-33$ \\
\hline $\mathrm{Na}+\mathrm{K}$ & до 30,4 & $36-43$ & - \\
\hline $\mathrm{Na}$, мГ/л & - & - & $49-54$ \\
\hline $\mathrm{pH}$ & $7,5-8,5$ & $7,0-8,5$ & $6,6-8,3$ \\
\hline $\begin{array}{l}\text { Минерализация, } \\
\text { мг/л }\end{array}$ & $\begin{array}{c}\text { весна: } 282-342, \\
\text { лето: } 75-252\end{array}$ & $100-300$ & $380-400$ \\
\hline Состав воды & $\begin{array}{c}\text { гидрокарбонатно- } \\
\text { кальциевые }\end{array}$ & $\begin{array}{c}\text { гидрокарбонатно- } \\
\text { кальциевые (или } \\
\text { натриево-кальциевые) }\end{array}$ & $\begin{array}{c}\text { сульфатно- } \\
\text { гидрокарбонатно } \\
\text { кальциево-натриевый }\end{array}$ \\
\hline $\mathrm{O}_{2}$ мг/л & $9,46-16,80$ & $6-8$ & $8,7-9,9$ \\
\hline $\mathrm{Cl}^{-}$, мг/л & $1,6-8,1$ & от десятых долей до 8-11 & - \\
\hline
\end{tabular}

Примечание: «*» - по Богданов, 1977; «**» - по Экология.., 1994; «***»- по Цыдыпов и др., 2017; «-» нет данных.

Для озера Гусиное характерны внутривековые и вековые циклы уровенного режима. С 1700 по 1885 год в озере были выделены 5 максимумов и 5 минимумов, с 20-40-летней внутривекой периодичностью (Гусиноозерская..., 2016), на фоне которых В. А. Обязовым (2014) выделены вековые (120-125 лет) катастрофические циклы в истории озера Гусиное. Максимальная ампдитуда колебания за период 1950-1990 год составляла 95 см (Экология..., 1994). Согласно данным В. А. Обязова (2014) с 1998 года на территории Забайкалья наступила маловодная климатическая фаза, характеризующаяся уменьшением количества атмосферных осадков, что обусловило снижение уровня вод в озерах, в том числе и в озере Гусиное.

Гидроботанические работы на озере Гусиное проведены в июле 2013-2014 годов с использованием общепринятых методов (Катанская, 1981), а также методик, апробированных авторами на водоемах Забайкалья (Базарова, 2012). При изучении растительного покрова в озере заложено 12 профилей (рис. 1), от уреза воды до максимальной глубины произрастания растений. Отбор фитомассы растений проведен прибором количественного учета гаммарид (КУГ, площадь захвата $0,25 \mathrm{~m}^{2}$ ), в сообществах харовых водорослей - дночерпателем Петерсена (площадь захвата $0,025 \mathrm{~m}^{2}$ ) которые использовались авторами при изучении сообществ водных растений и на других водоемах (Базарова, 2013). Всего было описано 89 
укосов. Фитомасса растений приведена в абсолютно-сухом весе. В озере преобладают монодоминантные сообщества, графическое описание сообществ представляет собой последовательный перечень видов-доминантов сменяющихся по профилю нарастания глубины.

\section{РЕЗУЛЬТАТЫ И ОБСУЖДЕНИЕ}

Флора озера. Сравнительный анализ многолетней динамики водной и прибрежноводной флоры озера Гусиное осложнен отсутствием детальных исследований макрофитов. В ранних работах (Гусиноозерская..., 2016; Рыбопромысловая..., 1939) указаны только массовые виды, создающие помехи рыбному промыслу. Больше сведений о растениях озера приведено в работе М. М. Кожова (1950). Во флоре озера по состоянию на 1927 году было указано 4 вида (табл. 1), для 1936 года - сусак, тростник, лучица (хара), рдесты, мох и лютик (Рыбопромысловая..., 1939). В 1947 году было зафиксировано 9 видов, в настоящее время зарегистрировано 27 видов из 21 семейства (табл. 2). В целом, наши исследования являются первой специальной гидроботанической работой, поскольку предыдущие исследования были ориентированы на нужды рыбной отрасли, в задачи которых не входило исследование видового и ценотического состава растительности озера.

В 2013-2014 годах, по сравнению с 1947 годом, не отмечена Nuphar sp., в то же время зарегистрированы $P$. amphibia, $N$. peltata и $C$. demersum. Скорее всего, последние три вида и ранее произрастали в озере, однако не указывались, так как не представляли помех для рыбного промысла. В начале XX века в озеро Гусиное проник чужеродный вид водных растений - E. canadensis. В период наших исследований он встречался в устьевых участках и на мелководье озера вдоль северного, западного и южного побережий. В озере Гусиное E. candensis не оказывает явного влияния на аборигенные виды. Согласно литературным данным, между харовыми водорослями и E. canadensis существуют конкурентные взаимоотношения (Синкявичене, 2010; Scheffer et al., 2007). Основным лимитирующим фактором для развития E. canadensis в экосистеме харовых озёр является не абсолютное валовое содержание Са в толще воды, а соотношение макрокомпонентов в водоёме (Van den Berg et al., 1999). Анализ химического состава водоемов Забайкалья (оз. Большая Еравна, Чивыркуйский залив и Посольский сор оз. Байкал), в которых E. canadensis распространена на больших площадях и формирует довольно плотные сообщества, показал, что в них концентрации ионов Са выше содержания таковых $\mathrm{Mg}, \mathrm{Cl}$ и суммы ионов К и $\mathrm{Na}$. B озерах Щучье, Гунда, Кенон и Гусиное, где доминирующим видом растительности являются харовые водоросли, E. canadensis укореняется локально небольшими зарослями на участках притока вод (заболоченные прибрежья или ручейки). При этом концентрации ионов Са в данных озерах ниже значений таковых $\mathrm{Mg}, \mathrm{Cl}$ и суммы ионов К и $\mathrm{Na}$ (Базарова, 2015).

Растительность озера. Современная пространственная структура растительности озера Гусиное во многом обусловлена как особенностями строения литорали, так и антропогенной нагрузкой. В настоящее время на большей части бентали озера макрофиты произрастают до глубин 8,5-11,0 м, максимально до глубины 13,0 м на юго-западном мелководье озера.

Литораль до глубины 11 м занимает 50,7 \% от общей площади озера. Литораль северной части озера находится под сильным воздействием сброса подогретых вод Гусиноозерской ГРЭС, в отводящем канале в которой располагаются садки осетрового рыбоводного хозяйства. В устьевой зоне реки Загустай происходит сброс очищенных сточных вод города Гусиноозерск, которые поставляют в озеро биогенные вещества. Здесь наблюдается позднее отмирание и раннее начало вегетации водных растений, массовое развитие нитчатых водорослей (глубины 2,0 м), являющихся индикаторами повышенной биогенной нагрузки.

На северном побережье озера было заложено 2 профиля: напротив реки Загустай (профиль I) и реки Тобхор (профиль III) (рис. 1). Профиль I имеет равномерный спад глубин, протяженность от уреза до 12 м составляет 2,5 км, преобладающие грунты - ил. Совокупность благоприятных факторов создают условия для развития зарослей Ph. australis, небольших 
Динамика водной флоры макрофитов озера Гусиное

\begin{tabular}{|c|c|c|c|}
\hline \multirow{2}{*}{ Таксон } & \multicolumn{3}{|c|}{ Года } \\
\hline & $1927 *$ & $1947 * * *$ & 2013-2014 \\
\hline Chara fragilis Desv. & - & ++ & +++ \\
\hline Ch. vulgaris L. $(=C$. foetida $)$ & - & ++ & + \\
\hline Nitella opaca L. & - & - & ++ \\
\hline Aegagropila linnaei Kütz. & - & - & ++ \\
\hline Fontinalis antipyretica Hedw. & - & +++ & +++ \\
\hline Sparganium natans $\mathrm{L}$. & - & - & + \\
\hline Potamogeton perfoliatus L. & - & - & ++ \\
\hline P. compressus $\mathrm{L}$. & - & - & + \\
\hline P. crispus $\mathrm{L}$. & - & ++ & + \\
\hline P. praelongus Wulf. & + & +++ & + \\
\hline P.obtusifolius Mert. et Koch & + & - & - \\
\hline Stuckenia pectinata (L.) Börner & + & ++ & + \\
\hline S. vaginata (Turcz.) Holub & + & - & ++ \\
\hline Sagittaria natans Pall. & - & - & + \\
\hline Butomus umbellatus L. & - & - & + \\
\hline Elodea canadensis Michx. & - & - & ++ \\
\hline Phragmites australis (Cav.) Trin. ex Steud. & - & +++ & +++ \\
\hline Scirpus radicans $\mathrm{Sch}$. & - & + & ++ \\
\hline Lemna minor $\mathrm{L}$. & - & - & ++ \\
\hline L. trisulca L. & - & - & + \\
\hline Persicaria amphibia (L.) S. F. Gray & - & - & +++ \\
\hline Nuphar sp. & - & ++ & - \\
\hline Ceratophyllum demersum L. & - & - & + \\
\hline Batrachium sp. & - & - & + \\
\hline Myriophyllum verticillatum L. & - & + & - \\
\hline M. sibiricum Kom & - & - & + \\
\hline Eleocharis acicularis (L) Roem et Sch. & - & - & + \\
\hline Hippuris vulgaris L. & - & - & + \\
\hline Nymphoides peltata (S.G. Gmel.) O. Kuntze & - & - & ++ \\
\hline Utricularia macrorhiza Le Conte & - & - & + \\
\hline ВСЕГО & 4 & 9 & 27 \\
\hline
\end{tabular}

Примечание: - - не указан; + - отмечен; ++ - субдоминант; +++ - доминант. * - (Гусиноозерская..., 2016); ** - (Кожов, 1950).

группировок $P$. amphibia и сложной мозаичной структуры сообществ погруженных растений (до глубины 3,0 м). На 4-х метровой глубине растительность представлена пятнами харовых водорослей, плотность зарослей которых увеличивается на глубинах 6,0 м. На этих жеглубинах выявлены отмирающие экземпляры $S$. vaginata. Скорее всего, S. vaginata имеет осенне-зимний период вегетации. Изменения в вегетационных сроках $S$. vaginata в озере Гусиное обусловлены влиянием теплых вод ГРЭС, что зафиксировано авторами на других водоемах-охладителях Забайкалья (Базарова, 2012). Последовательность распределения растительных сообществ на обследованном участке по градиенту глубины следующая (перечислены доминанты сообществ): Ph. australis (до глубин 0,5 м) $\rightarrow$ P. crispus + $P$. perfoliatus $+P$. amphibia (глубины $0,5-1,0$ м) $\rightarrow$ P. crispus + M. sibiricum $+S$. pectinata (до 3,5 м) $\rightarrow$ Charophyta $+S$. vaginata (с 4,0 до 8,5 м) $\rightarrow$ Charophyta (до 10,0 м). Значения средней фитомассы приведены в таблице 3. 
Средняя фитомасса водной растительности озера Гусиное

\begin{tabular}{|c|c|c|c|c|c|c|c|}
\hline $\mathrm{N}$ & Вид & $\mathrm{H}, \mathrm{M}$ & $\mathrm{ACB}, \Gamma / \mathrm{M}^{2}$ & $\mathrm{~N}$ & Вид & $\begin{array}{l}\mathrm{H}, \\
\mathrm{M}\end{array}$ & $\mathrm{ACB}, \Gamma / \mathrm{M}^{2}$ \\
\hline \multirow{12}{*}{ I } & P. amphibia & \multirow{3}{*}{1,5} & $5,6 \pm 2,8$ & \multirow{11}{*}{ V } & P. amphibia & \multirow{4}{*}{1,5} & $1,0 \pm 0$ \\
\hline & P. crispus & & $37,2 \pm 4,9$ & & P.perfoliatus & & $1,0 \pm 0$ \\
\hline & S. pectinata & & $72,0 \pm 25,5$ & & \begin{tabular}{|l|} 
E. canadensis \\
\end{tabular} & & $32,0 \pm 16,97$ \\
\hline & P. crispus & \multirow{2}{*}{2,0} & $124,0 \pm 53,7$ & & L. trisulca & & $8,0 \pm 0,1$ \\
\hline & M. sibiricum & & $48,0 \pm 15,6$ & & \begin{tabular}{|l|} 
E. canadensis \\
\end{tabular} & \multirow{2}{*}{2,0} & $226,4 \pm 117,1$ \\
\hline & S. pectinata & 3,0 & $148,8 \pm 21,8$ & & Chara sp. & & $661,52 \pm 27,2$ \\
\hline & Chara sp. & \multirow{2}{*}{4,0} & $160,6 \pm 8,5$ & & Nitella sp. & 4,0 & $3226,0 \pm 789,13$ \\
\hline & F. antipyretica & & $1,1 \pm 0,1$ & & F. antipyretica & 6,0 & $4168,0 \pm 667,51$ \\
\hline & Chara sp. & \multirow{3}{*}{6,0} & $290,4 \pm 63,9$ & & F. antipyretica & \multirow{2}{*}{8,0} & $652,0 \pm 113,14$ \\
\hline & L. trisulca & & $0,1 \pm 0$ & & L. trisulca & & $2,0 \pm 0$ \\
\hline & S. vaginata & & $10,4 \pm 0,4$ & & Chara sp. & 10,0 & $261,5 \pm 27,6$ \\
\hline & Chara sp. & 8,0 & $56,4 \pm 11,6$ & VI & Chara sp. & 10,1 & $226,4 \pm 15,8$ \\
\hline \multirow{2}{*}{ II } & \multirow{2}{*}{ Chara sp. } & 2,0 & $48,8 \pm 22,1$ & \multirow[b]{2}{*}{ VII } & Chara sp. & 4,0 & $405,4 \pm 151,7$ \\
\hline & & 4,0 & $390,8 \pm 64,2$ & & F. antipyretica & 6,0 & $3224,0 \pm 1743,7$ \\
\hline \multirow{5}{*}{ III } & Chara sp. & 1,5 & $30,0 \pm 18,3$ & \multirow{10}{*}{ VIII } & P. amphibia & \multirow{2}{*}{1,5} & $15,0 \pm 3,5$ \\
\hline & P. praelongus & 2,0 & $10,0 \pm 0,1$ & & N. peltata & & $14,6 \pm 4,7$ \\
\hline & $F$. antipyretica & 4,0 & $157,2 \pm 30,3$ & & E. canadensis & 2,0 & $221,3 \pm 55,6$ \\
\hline & Chara sp. & 6,0 & $661,5 \pm 184,9$ & & E. canadensis & & $84,0 \pm 31,1$ \\
\hline & Chara sp. & 8,0 & $321,3 \pm 48,6$ & & \begin{tabular}{|l|} 
Chara sp. \\
\end{tabular} & 3,0 & $60,8 \pm 020,5$ \\
\hline \multirow{11}{*}{$\begin{array}{l}\text { I } \\
\text { V }\end{array}$} & P. amphibia & \multirow{4}{*}{1,5} & $3,6 \pm 1,0$ & & F. antipyretica & 4,0 & $875,28 \pm 0$ \\
\hline & P.perfoliatus & & $5,0 \pm 2,3$ & & Chara sp. & 60 & $129,4 \pm 88,1$ \\
\hline & S. pectinata & & $9,6 \pm 0,1$ & & F. antipyretica & 0,0 & $2287 \pm 193,75$ \\
\hline & L. trisulca & & 0,1 & & A. linnaei & 8,0 & $494,5 \pm 0$ \\
\hline & P. perfoliatus & 2,0 & $13,2 \pm 0,9$ & & A. linnaei & 10,0 & $15,4 \pm 0$ \\
\hline & Chara sp. & \multirow{3}{*}{5,0} & $404,0 \pm 209,3$ & \multirow{3}{*}{ IX } & Chara sp. & \multirow{3}{*}{6,0} & $1922,5 \pm 0$ \\
\hline & L. trisulca & & $1,0 \pm 0$ & & F. antipyretica & & $1,0 \pm 0$ \\
\hline & Potamogeton sp. & & $1,0 \pm 0$ & & S. pectinata & & $1,0 \pm 0$ \\
\hline & Chara sp. & 8,2 & $4084,0 \pm 1473,6$ & \multirow{3}{*}{ XII } & \multirow{3}{*}{ Chara sp. } & 4,9 & $117,3 \pm 13,2$ \\
\hline & \multirow{2}{*}{ Chara sp. } & \multirow{2}{*}{9,3} & \multirow{2}{*}{$1892,0 \pm 65,1$} & & & 5,4 & $29,0 \pm 7,8$ \\
\hline & & & & & & 7,1 & $82,8 \pm 31,93$ \\
\hline $\mathrm{X}$ & Chara sp. & 4,9 & $117,3 \pm 6,6$ & $\mathrm{XI}$ & Chara sp. & 7,1 & $82,84 \pm 26,3$ \\
\hline
\end{tabular}

Примечание: $\mathrm{N}$ - номер профиля; Н - глубина; АСВ - абсолютно-сухой вес растений; \pm - стандартное отклонение.

Литораль в районе реки Тобхор (профиль III) (рис. 1) протяженностью 2,3 км характеризуется равномерным спадом глубин, грунт - ил. Расположение ГРЭС на берегу озера уменьшает доступ населения к данному участку. Это создает условия для сохранения мощных зарослей Ph. australis, в нижнем ярусе которых выявлены харофиты. Сообщества харовых водорослей и мха $F$. antipyretica чередуются вплоть до глубины 8,5 м. На данном участке озера отмечены сообщества $P$. praelongus, ранее (в 1947 году) указывающихся в роли доминантов растительного покрова озера. По мере нарастания глубины растительность образует следующий ряд (указаны доминанты сообществ): Ph. australis (до 0,3 м) $\rightarrow$ $P$. praelongus $(1,0-2,0$ м) $\leftrightarrow$. antipyretica $\leftrightarrow$ Chara sp. (1,0-8,5 м) (табл. 2).

Южное побережье озера обследовано в районе устья реки Цаган-Гол (профиль VIII) (рис. 1). На южном побережье большее влияние на структуру растительности оказывает мозаичный характер грунтов, неравномерный спад глубин. Здесь же создаются наиболее благоприятные условия для развития чужеродного вида E. canadensis. Данный район характеризуется сложным морфометрическим строением дна, наиболее протяженной литоралью (до глубины 13 м протяженность составляет около 5,0 км). Постепенное увеличение глубин до 4,0 м 
(расстояние от уреза 1,2 км), на расстоянии $\approx 2,0$ км сменяется на участок с глубиной 2,0 м, известным как «осередыш». На расстоянии 4,2 км идет резкий рост глубин до 10,0 м. Грунт до глубин 1,0 м песчано-галечный, на больших глубинах - ил, на «осередыше» - уплотненный галечник. Растительность представлена следующими группировками: Ph. australis (прибрежье изреженная полоса до глубин 0,3 м) $\rightarrow$ P. amphibia (в устье, песок, галька, глубины 1,0-1,5 м) $\leftrightarrow$. peltata (песок + ил, глубины 1,5-2,0 м) $\leftrightarrow$ E. canadensis (ил, глубины $1,0-2,0$ м) $\rightarrow$ Charophyta (ил, глубины 3,0-4,0) $\rightarrow$ P. perfoliatus (песок, ил, глубины 2,5 м) + $P$. amphibia (галька, ил, 2,0 м) $\rightarrow$ Charophyta $+F$. antipyretica (ил, более 3,0 м) (табл. 3).

Различия в пространственной структуре растительности западного и восточного побережий обусловлены их положением относительно ветров, господствующих в период открытой воды.

Западный подветренный берег отличается большей изрезанностью береговой линии, наличием защищенных от волновой активности затишных участков бухт и заливов, в которых создаются благоприятные условия для развития растений. Литораль западного побережья озера изучена на 4 профилях (IV, V, VI, VII) (рис. 1), которые соответственно расположены напротив водозабора ГРЭС, рек Бараты, Сангинэ и Нарин-Горхон. Профиль IV характеризуется довольно резкими перепадами глубины от уреза до 4,0 м с последовательной сменой грунтов: с каменисто-галечных на песчаные, глубже - на песчано-илистые и илистые. Особенности строения литорали и характер грунта определили последовательность роста растений по градиенту глубины. На глубинах 1,5 м зафиксирован пояс зарослей $P$. perfoliatus и скопления E. canadensis, глубины с 2,0 до 8,0 м заняты Charophyta. Структура растительности следующая: P. perfoliatus $\leftrightarrow$ E. canadensis $\rightarrow$ Charophyta. Профиль V заложен в заливе Бараты, куда впадает одноименный ручей. При этом наличие некоторых закрытых условий залива определяет разнообразие растительного покрова. Здесь прибрежная часть немного заболочена, в урезовой зоне до изобаты 1,5 м встречаются группировки $P$. perfoliatus, S. pectinata, E. canadensis, P. amphibia, также отмечена L. trisulca. С глубины 2,0 м роль доминанта переходит к $F$. antipyretica с участием $N$. ораса. Смена растительности по градиенту глубины следующая: P. perfoliatus $\leftrightarrow$ S. pectinata $\leftrightarrow$ E. canadensis $\rightarrow F$. antipyretica $\leftrightarrow N$. ораса $\leftrightarrow$ Charophyta (с глубины 1,5-2,0 до 8,5 м). Профили VI и VII имеют довольно крутой подводный склон, схожие характер грунта и структуру растительности. Здесь растительность выявлена с 2-х метровых глубин и представлена 2 видами из Charophyta и Bryophyta, образующих плотные заросли. Фитомасса $F$. antipyretica колеблется в пределах

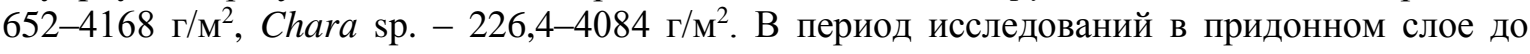
глубины 3,0 м отмечены скопления нитчатых водорослей. Между профилями VII и VIII на глубинах около 5 м встречается S. vaginata. В целом, последовательность распределения сообществ на западном побережье можно объединить в виде обобщенного ряда: P. perfoliatus $\leftrightarrow$ S. pectinata $\leftrightarrow$ E. canadensis $\leftrightarrow P$. amphibia (от уреза до 1,5 м) $\rightarrow F$. antipyretica $\leftrightarrow$ Nitella sp. $\leftrightarrow$ Chara sp. (с глубины 1,5-2,0 до 8,5 м) (табл. 3).

Восточное побережье озера (профили II, IX, X, XI, XII) (рис. 1) подвержено волновой активности, что обуславливает характер распределения грунтов и бедность сообществ. Так, с уреза до глубины 4,0 м дно песчаное, на глубинах более 4,0 м - илистое. Харовые водоросли произрастают на глубинах от 4,0 до 11,0 м. При этом водоросли характеризуются небольшими значениями фитомассы, в пределах 29,0-129,44 г/м². Профиль II расположен на северозападном побережье, где находится город Гусиноозерск. Растительный покров в виде изреженных полос $N$. peltata выявлен на глубине 1,5 м, который сменяются на харовый. В период исследований на глубине 2,0 м зафиксированы скопления нитчатых водорослей, что может свидетельствовать о биогенной нагрузке с территории города. Профиль IX заложен в истоке реки Баин-Цаган, характеризуется широким песчаным мелководьем протяженностью до 1,1 км и затем резким спадом глубин. В данных условиях растительность не формирует четко выраженных полос, а представлена пятнами различной плотности. На глубинах 2,0 м зарегистрированы группировки M. sibiricum, P. perfoliatus, C. demersum (табл. 3), на больших глубинах растут Charophyta, Bryophyta, A. linnaei. 
Что касается многолетних изменений, мы располагаем краткими данными по растительности озера, представленными в работе М. М. Кожова (1950). Автор отмечает, что 1947 году заросли Ph. australis занимали прибрежье вдоль северного, западного берегов и в юго-западной оконечности в устье реки Цаган-Гол. Сообщества P. crispus, S. pectinata (P.pectinatus) формировали хорошо выраженный пояс вдоль западного побережья. Вперемежку с рдестовыми с прибрежной полосы появляются виды рода Chara (Ch. fragilis, Ch. foetida). С глубины 6,0 м произрастали виды рода Nitella sp. и мхи. По описаниям в 1947 году в озере наблюдался сток реки Баин-Гол (Кожов, 1950), предположительно данный период характеризовался высоким уровнем воды в озере.

В настоящее время, мы наблюдаем некоторое сокращение зарослей Ph. australis, сообществ P. crispus, S. pectinata и P. praelongus на западном побережье озера. В то же время в озере, как и в предыдущие годы, доминируют сообщества харовых и мхов; отмечается некоторое снижение глубины и площади их произрастания. Если ранее харовые регистрировались до глубин 15-20 м, то в настоящее время единичные экземпляры представителей Charophyta встречаются на глубинах до 13,0 м. Сообщества мха Fontinalis сохранились лишь по западному побережью, образуя плотные сообщества с высокими значениями фитомассы (табл. 3). К сожалению, в ранних публикациях, нет данных о значениях фитомассы харовых водорослей, но в связи с тем, что там имеются упоминания о разреженных зарослях, можно предположить, что, скорее всего, в многолетнем аспекте фитомасса харовых существенно возросла.

Предположительно, современное состояние растительного покрова озера Гусиное - это результат воздействия комплекса факторов, связанных со снижением уровня, изменениями в температурном режиме и гидрохимическом составе вод в озере. Как было ранее показано, период наших исследований приходится на маловодную климатическую фазу (Обязов, 2014), что сопровождается снижением уровня воды и приводит к осушению прибрежной зоны, сдвигу уреза воды. Это вызвало временное ухудшение условий для роста прибрежно-водной растительности и рдестовых на западном побережье озера. Рост увлажненности на территории Забайкалья в будущем приведет к восстановлению зарослей Ph. australis и рдестовых. Подобные изменения в распределение растительности вследствие снижения уровня воды нами зарегистрированы в литорали озера Арахлей, расположенного в Восточном Забайкалье (Kuklin, Bazarova, 2019; Bazarova, 2020). Рост фитомассы харовых водорослей на фоне роста содержания сульфатов и изменений температурного режима также зафиксирован в озере Кенон, использующемся в качестве водоема-охладителя Читинской ТЭЦ-1 (Базарова, 2012). Согласно литературным данным (Madsen et al., 2006; Ginberge, Springe, 2008), интенсивный рост харофитов начинается, когда температура воды достигает 8-10 ${ }^{\circ} \mathrm{C}$. Увеличение плотности зарослей мхов, возможно, также обусловлено изменением температурного режима водоема. Оптимальными условиями для развития Fontinalis является диапазон температуры 5-15 ${ }^{\circ} \mathrm{C}$. При достижении $10{ }^{\circ} \mathrm{C}$ наблюдается максимальный рост их ризоидов (Debén et al., 2018). Данные группы растений довольно устойчивы к высоким концентрациям тяжелых металлов (Lambert, Davy, 2011), при этом увеличение содержания биогенных элементов негативно влияет на них (Kufel, Kufel, 2002; Pukacz et al., 2013; Debén et al., 2019).

\section{ЗАКЛЮЧЕНИЕ}

В ходе гидроботанических исследований озера Гусиное проведенных в 2013-2014 годах, получены современные данные о видовом разнообразии и пространственной структуре растительности. В период исследований в озере выявлено 27 видов из 21 семейства. Макрофиты произрастают до глубины 13,0 м в юго-западной части озера. В остальной части озера растения встречаются до глубин 8,5-11,0 м. Современная водная флора и пространственная структура растительности озеро Гусиное во многом обусловлены комплексом факторов (строение литорали, динамика уровня воды, повышение температуры и состав вод и др.), как природного, так и антропогенного характера. Литораль северной части 
озера находится под воздействием сброса подогретых вод Гусиноозерской ГРЭС, в отводящем канале которой располагаются садки осетрового рыбоводного хозяйства. В южной части озера наибольшее влияние на структуру растительности оказывают особенности строения литорали и мозаичный характер грунтов. Различия в пространственной структуре растительности западной и восточной части озера обусловлены их положением относительно господствующих ветров. В многолетнем плане, несмотря на значительную антропогенную нагрузку, доминантами растительности остаются Charophyta и Bryophyta

Появившийся, в начале XX века чужеродный вид E. canadensis не оказывает явного влияния на аборигенные виды озера Гусиное. С рыбохозяйственной точки зрения зарастание водоема представляет собой негативный процесс. Представляется крайне важным, чтобы при проведении работ по рыбохозяйственной мелиорации мелководий естественная система самоочищения водоема, важным компонентом которой является растительный покров водоема, не пострадала. Возможное увеличение поступления биогенных элементов, особенно фосфора, скорее всего, окажет негативное влияние на заросли харовых водорослей и мхов, что, в свою очередь, может неблагоприятно отразится на других компонентах экосистемы озера.

Благодарности. Авторы выражают благодарность Д. В. Матафонову за помощь в отборе проб, К. В. Гориной за помощь в оформлении карты.

Работа выполнена в рамках госзадания ФГБУН ИПРЭК СО РАН по теме Тема «Геоэкология водных экосистем Забайкалья в условиях современного климата и техногенеза, основные подходы к рациональному использованию вод и их биологических ресурсов», № FUFR-2021-0006.

\section{Список литературы}

Базарова Б. Б. Многолетние изменения растительности оз. Кенон (Забайкальский край) // Известия Иркутского государственного университета. Серия «Биология. Экология». - 2012. - Т.5, № 4. - С.18-23.

Базарова Б. Б. Elodea canadensis Michaux и харовые водоросли оз. Кенон (Забайкальский край) // Российский журнал биологических инвазий. - 2013. - № 3.- С. 7-15.

Базарова Б. Б. Содержание химических элементов в Elodea canadensis Michx. в водоемах Забайкалья// Вода: Химия и экология. -2015 . - С. 39-42.

Бобкова Е. А., Иметхенов А. Б. Влияние сточных вод г. Гусиноозерск на ихтиофауну оз. Гусиное // Вестник Восточно-Сибирского государственного университет технологии и управления. - 2011. -Т. 3, № 34. - С. $176-181$.

Богданов В. Т. Гидрохимическое состояние вод озера Гусиное // Гидрохимия рек и озер в условиях резко континентального климата. - Владивосток: ДВНЦ АН СССР, 1977. - С. 113-123.

Гусиноозерская экспедиция П. С. Михно 1927 г. (Динамика природных комплексов Гусиноозерской котловины и аспекты культурного наследия Селенгинского среднегорья) / [Ред. Э.А. Батоцыренова]. - Улан-Удэ: ЭКОС, 2016. - $168 \mathrm{c}$.

Дугаров Ж. Н., Бурдуковская Т. Г., Батуева М. Д., Балданова Д. Р., Сондуева Л. Д., Жепхолова О. Б., Мазур О. Е. Изменения видового состава паразитов окуня Perca fluviatilis оз. Гусиное (бассейн оз. Байкал) вследствие депрессии и последующего восстановления численности хозяина// Экология. - 2018.- № 3. - С. 220-224.

Дугаров Ж. Н., Пронин Н. М. Разнообразие фауны и динамика видового богатства и доминирования в сообществах паразитов в возрастном ряду речного окуня Perca fluviatilis // Экология. - 2017. -№ 1. - С. $20-27$.

Катанская В. М. Высшая водная растительность континентальных водоемов СССР. Методы изучения. - Л.: Наука, 1981. - 187 c.

Кожов М. М. Пресные воды Восточной Сибири. - Иркутск: ОГИЗ, 1950. - 367 с.

Матафонов Д. В., Базова Н. В. Новый подход к организации сети станций для мониторинга озёрных водоёмов Бурятии по организмам макрозообентоса: первые результаты применения и анализ пространственного распределения амфипод в озёрах Еравнинской системы как пример его реализации // Известия Иркутского государственного университета. Серия «Биология. Экология». - 2018. - Т. 24. - С. 86-109.

Матвеев А. Н., Юрьев А. Л., Самусенок В. П., Вокин А. И., Самусенок И. В. Изменение состава ихтиофауны оз. Гусиное (водоема-охладителя Гусиноозерской ГРЭС) и роли в ней чужеродных видов // Экология водоемовохладителей энергетических станций: сб. материалов (Чита, 13-16 сентября, 2017 г.). - Чита: ЗаБГУ. 2017. - С. $340-345$.

Обязов В. А. Изменения современного климата и оценка их последствий для природных и природноантропогенных систем Забайкалья: авторефер. дис. ... докт. геогр. наук. - Казань: КФУ, 2014. -38 с. 
Рыбопромысловая карта озера Гусиное Селенгинского района Б.М.А.С.С.Р. [Гл. инж. Синельников; ГИП Соловьев; нач.сект.Ульяхин]. - М.: ВНИОРХ, 1939. - 10 с.

Синкявичене 3. Elodea canadensis L. в естественных водоёмах Литвы // Гидроботаника 2010: Мат. межд. конф. по водным макрофитам. Ярославль: Принт Хаус, 2010. - С. 275-277.

Семерной В. П., Матафонов Д. В., Базова Н. В. Фауна и пространственное распределение малощетинковых червей (Annelida:Oligochaeta) в озере Гусиное (бассейн озера Байкал) // Известия Иркутского государственного университета. Серия «Биология. Экология».. - 2014. - Т. 10. - С. 92-107.

Цыдыпов Б. З., Андреев С. Г, Аюржанаев А. А., Содномов Б. В., Гуржапов Б. О., Батоцыренов Э. А., Павлов И. А., Ширеторова В. Г., Ульзетуева И. Д., Габеева Д. А., Раднаева Л. Д., Гармаев Е. Ж. Влияние сбросов Гусиноозерской ГРЭС на термический и гидрохимический режим озера Гусиное // Известия Иркутского государственного университета. Серия «Биология. Экология». - 2017. - Т. 22. - С. 135-150.

Чебунина Н. С., Пахахинова 3.3., Бешенцев А. Н., Батоев В.Б. Оценка влияния сброса теплых вод Гусиноозерской Грэс на динамику ледового режима озера Гусиного (Западное Забайкалье) // Научный журнал КубГАУ, - 2016. - № 116 (02). - С. 1-8.

Шевелева Н. Г., Зайцева Е. П. Зоопланктон озера Гусиное в зоне влияния Гусиноозерской ГРЭС // Вода: химия и экология. - 2015. - № 5. - С. 41-46. $199 \mathrm{c}$.

Экология озера Гусиное / [Ред. Борисенко И. М., Пронин Н. М.]. - Улан-Удэ: Изд-во БНЦ СО РАН, 1994. -

Bazarova B. B. Vegetation state of lake Arakhley during water change // Proceeding of International scientific on aquatic macrophytes "Hydrobotany 2020" (Borok, 17-21 Octeber, 2020). - Yaroslavl: Filigran, 2020. - P. 13-14.

Debén S., Aboal J. R., Giráldez P., Varela Z., Fernández J. A. Developing a Biotechnological Tool for Monitoring Water Quality: In Vitro Clone Culture of the Aquatic Moss Fontinalis antipyretica // Water. - 2019. - Vol. 11 (1). - P. 145 .

Grinberga L., Springe G. Potential impact of climate change on aquatic vegetation of river Salaca, Latvia // Proceedings of the Latvian Academy of Sciences. - 2008. - Vol. 62. - P. 34-39.

Kufel L., Kufel I. Chara beds acting as nutrient sinks in shallow lakes - a review // Aquatic Botany. - 2002. - Vol. 72, N 3-4. - P. 249-260.

KuklinA. P., Bazarov B. B. Macrophytes in the littoral of lake Arakhley in different states of water regime // Ekológia (Bratislava). - 2019. - Vol. 38, N 3. - P. 225-239.

Lambert S. J., Davy A. J. Water quality as a threat to aquatic plants: discriminating between the effects of nitrate, phosphate, boron and heavy metals on charophytes // New Phytologist. - 2011. - N 189. - C. 1051-1059.

Madsen D. J., Wersal M. R., Tyler M., Gerard P. The distribution and abundance of aquatic macrophytes in Swan lake and Middle lake, Minnesota // Journal of Freshwater Ecology - 2006. - Vol. 21. - P. 421-429.

Pukacz A., Pełechaty M., Pełechata A. The relation between charophytes and habitat differentiation in temperate lowland lakes // Polish journal of ecology. -2013. - Vol. 61 (1). - P. 105-118.

Scheffer M., Van Nes E. H. Shallow lakes theory revisited: various alternative regimes driven by climate, nutrients, depth and lake size // Hydrobiologia. - 2007. - Vol. 584, N 1. - P. 455-466.

Tsydenova B. V., Dagurova O. P., Garankina V. P., Dambaev V. B., Matafonov D. V., Baturina O. A. Abundance and taxonomic composition of bacterioplankton in freshwater Lake Gusinoye (Buryatia) in the warm water zone of the Gusinoozerskaya thermal power plant // Journal of Siberian Federal University. Biology. - 2018. - N 11 (4). - P. 356-366.

Van den Berg M. S., Scheffer M., Van Nes E. H., Coops H. Dynamics and stability of Chara sp. and Potamogeton pectinatus in a shallow lake changing in eutrophication level // Hydrobiologia. - 1999. - Vol. 409. - P. 335-342.

Bazarova B.B., Kuklin A.P. On the current state and long-term dynamics of the flora and vegetation of Lake Gusinoe (Republic of Buryatia) // Ekosistemy. 2021. Iss. 25. P. 72-81.

As a result of hydrobotanical research carried out in the summer of 2013-2014. 27 species from 21 families are registered in the lake.Macrophytes grow up to the depth of $13.0 \mathrm{~m}$ on the southwestern shore of the lake. The current state of the vegetation cover of the lake is due to a complex of factors (the structure of the littoral, the dynamics of the water level, changes in temperature, water composition, etc.), both natural and anthropogenic. At the same time, in the long-term plan, despite the significant anthropogenic load, the dominant vegetation remains Charophyta and Bryophyta. The alien species E. canadensis, which appeared at the beginning of the XX century, does not have a clear effect on the native species of Lake Gusinoe.

Key words: aquatic vegetation, ecosystems lake, Lake Gusinoe, charophyta, bryophyta.

Поступила в редакичию 20.11.20

Принята к печати 11.02.21 